THE EUROPEAN JOURNAL OF LIFE WRITING VOLUME VIII(2019)R38-R42

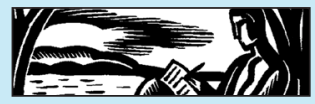

Alison E. Martin, Lut Missinne and Beatrix van Dam (eds.). Travel Writing in Dutch and German, 1790-1930. Modernity, Regionality, Mobility. (New York and London: Routledge, 2017, ISBN 9781138999503 )

\title{
Sandra Vlasta
}

Johannes Gutenberg University Mainz

The study of travel writing has been a growing field both in historical and in literary studies during the past thirty years. The founding of research centres and journals dedicated to the subject underline this increased interest, so does the book series Research in Travel Writing, edited by Peter Hulmes and Tim Youngs, two well-known scholars in the field, and published by Routledge. The collected volume Travel Writing in Dutch and German, 1790-1930. Modernity, Regionality, Mobility is one of the latest books in this series. In this volume, that goes back to a conference held in Münster in 2013, the editors Lut Missinne (Münster), Alison E. Martin (Reading) and Beatrix van Dam (Münster) combine chapters on travel writing in Dutch and German about the Dutch- and German-speaking regions. Thus, the book comprises contributions on German travellers in Dutch-speaking regions including Belgium, and Dutch-speaking travellers in German-speaking regions but also travellers in the then Dutch colony of Suriname and in the Dutch East Indies as well as archival and scientific travellers' journeys in both the German- and the Dutch-speaking regions. In so doing, the collection sheds light on the cultural and intellectual exchange between these regions and concentrates on a body of hitherto less studied travellers. Travelling was very popular in the nineteenth century, not least due to changing material and financial conditions. Still, modes and perceptions of travel varied: accordingly, as the editors explain in their introduction, a further aim of the volume is to investigate the different motivations, forms and destinations of travels in the Dutch-and German-speaking regions. In fact, the travellers under scrutiny are as varied as professional scholars, writers, art dealers, soldiers, (female) explorers and scientific collectors. Furthermore, the specific focus of the volume allowed for the integration of new areas of research and first findings, for 
instance on German-speaking writers on Suriname or the (mostly unpublished) egodocuments on travels by Dutch in Germany.

Travel Writing in Dutch and German has an interdisciplinary approach and combines contributions by scholars from literary and history studies. The differences in the approaches are notable and the confrontation is informative, although the single contributions (and the readers of the volume) would have profited from closer connections and mutual references. Thus, the volume's aim to methodologically combine narrative perspectives with a socio-historically contextualised approach is not achieved in all of the contributions. However, the chapters succeed in stressing the awareness of the interaction of travel as an activity, its respective context and the putting into writing of travel accounts.

The volume is structured in three parts: section I, entitled "Foreign Neighbours", shows how neighbouring countries can serve as examples for "otherness". In particular, the individual contributions in this section show how German and French travellers' perception of Belgium and Flanders was influenced by the political context at the time. The second section, "Travel and New Ways of Circulating Knowledge" deals with travellers that expressively seek after knowledge and aim to communicate their findings to their readers. The third section, eventually, is entitled "Mediating Knowledge" and concentrates on different ways of mediating information in the long nineteenth century.

The first section opens with Hubert Roland's contribution on German travellers in Flanders and Belgium. As he shows, the travellers' perception was highly influenced by their political opinions and concentrated on the newly born state of Belgium-still, individual opinions varied. For instance, whereas Johanna Schopenhauer backed the Flemish movement and interpreted the Belgian revolution as manipulated by France, other writers were in favour of the Belgian syncretic model, a mix of Romance and Germanic influences. Either way, German travellers in Flanders and Belgium often travelled with seventeenth century representations of the Low Countries in their minds and compared what they saw with images they were familiar with from paintings. This is also true for French and German travellers in the Netherlands as Kim Andringa describes in her contribution. Compared to France and the German countries, the Netherlands had fallen behind politically and economically. However, with the famous images, for instance by Pieter Paul Rubens, in mind, the travellers either saw the Netherlands as a place where they could escape the developments of modern society or-and this is true mainly for the German travellers-they used their impressions of the country to emphasise their own progress. Finally, Robbert-Jan Adriaansen concentrates on a particular group of travellers, namely the Wandervögel 
soldiers, i.e. members of a German bourgeois youth movement during the First World War. As he shows, they were particularly interested in the Flemish idyllic life and idyllic soul which they found very inspiring. To them, Flanders and the way of life they found there was a source of inspiration which they saw as an example for a post-bourgeois Germany to be realised after the war.

In the second section on travellers seeking knowledge, Alison E. Martin focusses on Ida Peiffer's Second Voyage round the World (1856). She in particular concentrates on Pfeiffer's role as a collector of specimens in the Dutch East Indies and thus her important role in preserving and furthering scientific knowledge about that region. Martin compares Pfeiffer's influential role in science to her travelogue, where little about these activities can be found. Rather, in her account Pfeiffer seems to stick to the role model (and the norms) for an Austrian woman in the mid-nineteenth-century. Whereas Pfeiffer collected specimen for the archive, the travellers that Herman Paul investigates in his contribution, travel to archives. In particular, he examines historians that were sent abroad on behalf of the Hanseatic Historical Association in order to find documents about this society. Paul describes the context of this endeavour, he characterises the typical travellers that would be sent out and the way they would typically go about their task. Furthermore, he shows the discrepancy between the idea that all Hanseatic sources could be covered by these journeys and the actual project that could, in fact, never be finished. However, as Paul underlines, these archival travellers' journeys resulted in three multi-volume book series that are still used as valuable sources by historians today. Carl Haarnack analyses German-language travel writing (and other texts) on Suriname, a South American Dutch colony until 1975. Whereas Dutch travel accounts on this region have already been researched, many of the sources in German have not been looked at yet. This, however, as Haarnack shows, is a worthwhile undertaking, in particular with regard to the differing representations of the former colony. Specifically, German travellers are more critical about slavery, especially from the middle of the nineteenth century onwards. At the same time, they are more open than their Dutch counterparts when it comes to the sexual relationships between European men and female slaves and in so doing reveal the complexity of the concept of slavery. The final contribution in this section discusses Louis Couperus's depiction of Africa in his letters that were published in a volume in 1921. Carl Niekerk shows how Couperus is critical of tourism, but at the same time gives practical information for tourists. Mainly, though, Nierkerk is interested in Couperus's narrative strategies-combinations of text 
and image, a sense of incompleteness, collage-like combination of texts-through which he succeeds in engaging his readers. In this way, the travelogue reflects on our perception of reality as well as how we position ourselves and the 'other' in it.

The third and final section of the volume focusses on the different ways knowledge connected to travel is mediated. The first contribution in this section concentrates on Dutch travellers in Germany and identifies their preferred destinations as well as the reasons for these choices. In fact, Arianne Baggerman and Rudolf Dekker present a major research project in which they have compiled inventories of so-called egodocuments by Dutch travellers between 1500 and 1918. These in large part unpublished documents show how the practice of travelling changed over the long nineteenth century. As Baggerman and Dekker show, the German states became more interesting to the Dutch travellers from 1800 onwards. However, the preferred destinations changed through time: whereas in the first half of the nineteenth century, the river Rhine and the ruins along it (together with the folk tales that surround these places) were a major attraction, later travellers preferred more southern regions, in particular the Alps (from where they could then travel on to Switzerland and Italy). In their article, the two scholars also identify instances where the travellers express the perceived 'otherness' of the Germans. Furthermore, they show the importance of mediation for the genre and, for instance, state that only in the twentieth century Dutch publishers specialised in the field of travel writing. The following chapter by Johan Oosterman investigates the scientific journey through Germany undertaken by the Dutch philologist Willem Jonckblot in the summer of 1842. He was in search of Middle Dutch literature, but at the same time was much aware that his journey was also an opportunity for him to 'network', as we would say today, and position himself as a scholar. The accurate description of Jonckblot's journey will thus remind the readers of Herman Paul's chapter on archival travellers in section two of the volume. Renata Schellenberg in her contribution concentrates on journals and shows how these were an important medium to find out about the other, the unknown (and thus to get to know oneself) in the German-speaking countries, where at the time the idea of a united nation was discussed. In fact, many travelogues were first printed in journals before being published as books. What is more, the information that is given on objects in these travelogues may encourage curiosity in the readers and make them want to go abroad themselves and see them. In Germany, Schellenberg argues, these descriptions facilitated the development of a (at first purely imaginative) national museum and collecting culture. In the final contribution in this volume, Anna P.H. Geurts 
challenges the view that with the development and professionalisation of tourism, the personal aspect of travelling became less significant. Geurts shows how, on the contrary, also from the second half of the nineteenth century onwards, face-to-face communication and personal contacts remained essential, for instance in order to gain access to (still mostly private) art collections. At the same time, these personal aspects of travel were increasingly combined with mechanisms of admission and the standardisation of travel activities. After this final chapter the volume finishes off with a helpful index.

By concentrating on travel writing in Dutch and German, the volume gives insight into the travel activities of neighbouring countries. The individual case studies show processes of cultural and intellectual exchange, they carve out various aspects of the perception of the respective 'other' and, at the same time, they touch upon ideas that were discussed at the time, such as nationhood and identity. Furthermore, the interdisciplinary approach of the volume shows the breadth of travel writing studies that corresponds to the numerous different activities that can be summarised under the term 'travel (writing)'. The collection is useful both to scholars interested in a particular topic treated in one of the case studies and to those who want to get an overview of travel writing in the German- and Dutch-speaking context. Last, but not least, it complements our knowledge about the many different modes and motivations of travelling in the long nineteenth century. 